\title{
THE SCOPE OF AN INTEGRATED ANALYSIS OF TRUST, SWITCHING BARRIERS, CUSTOMER SATISFACTION, AND LOYALTY
}

\section{- Muath Alkhurshan, Husam Rjoub}

\begin{abstract}
This study investigated the impact of service quality, intimacy, trust, and playfulness on customer loyalty. The integrated variables were investigated alongside their effect on customer loyalty. Variance-based structural equation modeling with PLS (PLS-SEM) was selected to assess the proposed hypotheses, with the analysis sample of the study including 627 questionnaires distributed to the sampled subjects. The positive effect of service quality, playfulness, intimacy, trust, and satisfaction was found, and a statistically significant impact was shown of switching barriers and trust on customer loyalty. Contrastingly, the results found no significant effect of customer satisfaction on customer loyalty. Our study offers a deeper understanding of some of the most important factors concerning customer satisfaction and loyalty and the effect of these factors on increasing market share and competitive advantage. The research goal of this paper is to examine the impact of service quality on business competitiveness. Enterprises need to understand what service quality is and how it will help provide a great competitive advantage, e.g. how service quality models could allow managers to identify where problems with quality lie. This will help managers determine where to improve the efficiency and profitability of the overall performance of the enterprise. For service industries, service quality increases competitive advantage and long-term profitability. Service quality will help organizations compete efficiently and differentiate themselves from other enterprises striving to achieve the same goals. For this and other reasons, service quality should be seen as critically important for businesses.
\end{abstract}

Keywords: service quality, playfulness, customer satisfaction, competitiveness, switching barriers, customer loyalty JEL Classification: B32, M31, M37, M39

Received: December, 2019

1st Revision: February, 2020

Accepted: March, 2020

\section{INTRODUCTION}

Mobile service providers in Jordan have improved considerably, including Zain (36\%), Orange (33\%), and Umniah (31\%) (Department of Statistics of Jordan, 2017). The continuation of these companies has led to a wide range of high competition in attracting new customers and retaining current ones. Furthermore, factors such as the growth of the wireless internet, fourth-generation $(4 \mathrm{G})$ and broadband services will contribute to increases in subscriber numbers in the mobile telecommunication services market in Jordan. 
Increasing competition has been recorded in the last few years between various firms and companies that operate in various sectors, prompting enterprises to increase their efforts to maintain their clients and to attract new ones. This circumstance requires the need for more effective strategic planning that can fulfill the needs and desires of various clients based on their divergent interests. Retaining clients is also a long-term objective of firms wishing to survive in the market place (Boshoff \& duPlessis, 2009). In this sense, Deng et al. (2010) asserted that the development of customer loyalty is a strategic goal. The loyalty of clients towards a firm and its services and goods motivates them to show consistent purchase behaviors despite competitors' determined attempts to induce clients to change their purchasing behavior. Cheng et al. (2011) further emphasize that the key to achieving client retention is found in the satisfaction that results from creating and preserving long-term relationships with clients. Furthermore, Hong \& Cho (2011) claimed that customer loyalty mirrors their psychological attachment to the products and attitudinal sponsorship towards the business, i.e. it indicates their willingness to be part of the organization that provides them with products and services. While working on strengthening client loyalty, business owners can retain clients and consequently, profits can be enhanced (Lee, 2010). Previous studies have also highlighted the significant role of service quality, trust, intimacy, and switching barriers as a tool to manage customer loyalty (Deng et al., 2010; Kheiry \& Alirezapou, 2012).

It is of great importance to maintain close relationships with the existing customers by increasing their satisfaction, as stronger connections will be built, thus enabling companies to deliver highquality services. Accordingly, service quality is the main contributor in maintaining these strong bonds with the targeted customers, and this can only be achieved by concentrating on the existing aspects that can be manipulated by service providers such as satisfaction, loyalty, and trust.

The aim of this study is to explore the extension of existing marketing theories by inspecting a series of interdependence relationships between loyalty, satisfaction, trust, and many other exploratory variables. This aim indeed increases the complexity of our framework, which requires a superior method to handle such complexity. Hair et al. (2018) proposed variance-based structural equation modeling with PLS (PLS-SEM) as a test of the proposed hypotheses.

To date, investigations into this topic have been quite limited in the context of Middle Eastern countries. Hence, the current study will contribute to the existing literature by being the first study to examine the impact of customer satisfaction, customer trust, and switching barriers on customer loyalty as an integrated model in the Middle East. In addition, the research outcomes will provide a comprehensive explanation of the importance of customer trust, with switching barriers considered as an anchor to increase customer loyalty.

\section{THEORETICAL BACKGROUND}

\subsection{Service quality, customer satisfaction, and customer trust}

The high penetration rate of the cellphone industry in Jordan has shifted the focus of the mobile industry toward facilitating network coverage, the upgrading of networks, service quality, and competitive pricing in the hopes of attracting and retaining customers. Cellphone service providers should keep their promises with customers and provide services based on customer perceptions rather than customer satisfaction, as this will lead to high customer loyalty. The present 
study involves an empirical investigation relying on primary data that were collected using a set of quantitative and qualitative methods.

Quality is defined and measured in accordance with the demands of markets through a subjective comparison by the client of expected and perceived performance of services or products (Danish et al., 2018). While the quality of services relates to the client's general impression of the relative superiority and/or inferiority of an institution and its services (Didki et al., 2018), the establishment and support of competitive limits depends on the high-level of service quality supplied by the provider (Yoo \& Park, 2007). The development of various tools for measuring service quality has been the most discussed subject pertaining to service quality in the marketing literature (Lee, 2010; Didki et al., 2018).

Definitions of service quality have always relied on the agreed description of indicators of quality, including assurance, reliability, tangibles, responsiveness, and empathy (Zeithaml et al., 2008). Furthermore, several studies have affirmed the existence of positive correlations between service quality, customer satisfaction and loyalty (Budianto, 2019), with these variables found to be highly correlated. Managing service quality also leads to repeated sales, as it is capable of predicting customer's future purchase intentions, thus increasing the service provider's market share and returns by focusing on satisfaction to promote customer loyalty.

It should be highlighted that positive correlations between service quality and client satisfaction have been well-documented in different business areas. A higher quality of services will cause customers to be more satisfied with the services provided, and they will become more involved and engaged. One example of this process is how service quality has contributed to the increase in number of loyal clients in the metropolitan retail markets in Turkey. Turel \& Serenko (2006) indicated in the same line of research how perceived service quality and perceived value affected the satisfaction of clients in the mobile services industry, which leads to the deduction that satisfaction leads to client loyalty. In research that discussed the telecommunication service quality based on settlement service, technology innovation, communication guarantee, and value-added service, Jahanzeb et al. (2011) discovered that settlement related to an accurate and quick billing service increases client satisfaction. Taking all these results and factors into consideration, the study proposes that:

H1: Service quality has a positive impact on the satisfaction of mobile telecommunication services users.

H2: Service quality has a positive impact on user trust in mobile telecommunication services.

\subsection{Playfulness and customer satisfaction}

Service organizations always focus on delivering more than just the basic service, in a process involving what is referred to as organizational satisfiers (Nien-Te et al., 2016). In this regard, playfulness means adding certain entertainment features to the products or services offered to customers (Tsai \& Wang, 2017). These features might include new sounds and images (Pura, 2005). Also, Liu et al. (2011) contended that playfulness includes two main criteria: (a) it is stable and not strongly influenced by the surrounding environment, and (b) customer's personal experience with the product or service is a key factor in determining client's satisfaction. Playfulness 
is all-encompassing in everyday life. Nonetheless, characterizing playfulness is not an easy task (Nien-Te et al., 2016) since the expression ("play") is used differently by both researchers and laymen.

There are two feasible approaches to addressing this field of study. First, playfulness is defined as a motivational characteristic of persons. Persons with a high level of playfulness have enhanced performance and superior emotional responses. Second, playfulness is described as a situational trait of the communication between people in a particular situation and the situational playfulness is emphasized.

Previous studies have also discovered that playfulness is positively related to satisfaction (Kalia et al., 2017). A high degree of playfulness leads to positive satisfaction and mood. Akin to a positive effect, attitudinal playfulness results in satisfaction; pleasure is affected by the playful experience, i.e. a positive subjective experience that becomes a vital ground in doing an activity. When an individual "feels good" about an activity, it is essentially motivating and makes him or her become more engaged. In this regard, individuals use mobile services and experience playfulness due to the fact that they are more absorbed and interested in their interaction. Playfulness is strongly correlated with expected services use, resulting in customers' loyalty. Therefore, the present research suggests that:

H3: Playfulness has a positive impact on the satisfaction of mobile telecommunication services users.

\subsection{Intimacy and trust}

Intimacy is defined as the perceived psychological closeness that customers hold towards the service (Lee et al., 2012). Organizations should establish intimate relations with their customers by caring for their needs and expectations (Zhang et al., 2018). It is also to be noted that service providers work on creating such an intimate (close) relationships with customers and maintain them as they realize the importance of those connections. With regard to social and emotional bonds, the most important aspect is to have a consecutive satisfying experience with the delivered service. Pontiskoski \& Asakawa (2009) also stated that business dealings with customer intimacy strategy are client-centric in nature and their routine operations are dictated by the client's needs. According to Liang et al. (2009), intimacy with clients can be summarised in five stages, namely consideration, communication, commitment, conflict resolution, and relief. Both companies and clients are seeking intimate relationships (Zhang, 2018) where long-term feelings develop into a long-lasting emotional bond. Intimacy is also relatively similar to empathy being one of the dimensions of service quality. First, empathy mainly focuses on the aspects of attention and individual care. Second, intimacy is considered as having a satisfying experience with the products or services, and this makes clients feel intimate with a service provider to find it reliable in terms of generosity and competence (Liu et al., 2011). Hence, this study suggests that: H4:Customers' intimacy has a positive effect on the trust of mobile telecommunication services users. 


\subsection{Customer satisfaction and loyalty}

The definition of customer satisfaction deals with customers' response to the state of accomplishment. Mobile service providers and service quality in the telecommunication industry have been measured in previous studies using the price structure, mobile devices, call quality, inconvenience of procedures, value-added services, and client support (Orel et al., 2014). While the increased numbers of customers due to costs improve the efficiency of promotion and business condition (Deng et al., 2010), satisfaction influences positively clients' future purchase intent (Huddleston et al., 2009). Also, satisfaction acts as the main predictor of client loyalty (Cheng et al., 2011) and trust (Dabholkar \& Sheng, 2012). Several researchers such as Cheng et al. (2011) further argued that clients' satisfaction is more crucial than profit-making, explaining the significance of clients' satisfaction as a measure of clients' behavior (Cheng et al., 2011) and a crucial indicator of business efficiency (Sandada, 2013).

Furthermore, previous studies that investigated reasons affecting customer loyalty focused on the client's switching behavior and his/ her satisfaction. It was discovered that having a high level of satisfaction is equivalent to staying with the current service provider. Based on the combination of the information analysis and a case study conducted by Deng et al. (2010), it was found that the client's loyalty is a major predictor of the organizations' sustainability revealing that loyal clients do not consider undesired advertising and they also make word-of-mouth advertisement and referrals. Accordingly, it is proposed that:

H5: Customer satisfaction has a positive effect on the loyalty of mobile telecommunication services users.

\subsection{Trust and customer loyalty}

The conception of trust entails many elements. The client's trust is described as the confidence that clients have towards service providers (Boshoff \& duPlessis, 2009). In this respect, Chang (2012) asserted that the client's trust might be cognitive and affective in nature. Cognitively, customers are certain that the service provider is trustworthy and keeps its promises; affectively, customers do think that the service displays genuine concern about clients' needs with an intent to increase returns. Service providers are trusted as the clients believe that the services or products provided are beneficial for them (Dabholkar \& Sheng, 2012). It can be deduced that the development of customers' commitment to the service provider is affected by clients' trust due to the positive experience that they had with the services or products (Ratanavaraha et al., 2016). Hence, retailers should assure that clients are satisfied with the services in order to preserve their commitment.

It should also be emphasized that once clients trust the service provider, they become loyal (Deng et al., 2010). According to Hong \& Cho (2011), the reliability of business is the key contributor to attracting and maintaining loyal clients. Moreover, studies have also reported a positive correlation between the client's trust and loyalty (Lin \& Wang, 2006). In an investigation of clients' relations in the Swiss financial system, Avramakis (2011) discovered that the client's trust positively predicted loyalty. The same positive correlation was also found by Sirdeshmurk et al., (2012) who developed a theoretical basis for explaining the correlation between the client's loyalty and trust in the airline retailing industry. Therefore, this study proposes that:

H6: Trust has a positive effect on the loyalty of mobile telecommunication services users. 


\subsection{Switching barriers and customer loyalty}

Switching barrier refers to the act of switching from one provider to another when customers are dissatisfied or frustrated with the current service related to monetary, psychological, and social burden aspects causing them to switch to a new mobile service provider (Apostolos \& Evangelos, 2017). Previous research in service industries (Chang \& Chen, 2007) examined the costs incurred due to switching to another service provider (pre, set -up, post), post-switching submits to adapting and acquiring new processes, and uncertainty costs as the significant determinants of switching.

Although a positive correlation between switching barriers and clients' retention has been demonstrated in previous studies (Howshigan \& Ragel, 2018), it should be highlighted that clients' repurchase is not necessarily an indicator of loyalty as they may stop doing business for various reasons (Valenzuela, 2012). When evaluating the correlation between client loyalty and switching barriers, Colwell \& Hogarth-Scott (2004) argued that "hostage" behavior might reduce the probability of long-lasting relations between clients and businesses as clients may leave the business once they no longer feel like a hostage in the relations. Contrastingly, other studies have revealed a positive correlation between client loyalty and switching barriers (Nesset \& Helgesen, 2014). However, the probability of clients' behavioral loyalty grows when the element of switching barriers is high and specifically once the options of exit are limited. In light of this discussion, the study proposes that:

H7: Switching barriers has a positive effect on the loyalty of mobile telecommunication services users.

\section{RESEARCH OBJECTIVE, METHODOLOGY AND DATA}

A questionnaire was developed to examine the aspects of switching barriers, customer satisfaction, customer trust, and customer loyalty of Jordanian users of mobile telecommunication services. The questionnaire was developed based on the previous studies in which reliability and validity indicators have been reviewed. By employing Brislin's back-translation procedure, the original survey items were translated into Arabic before being back-translated into English. Subsequently, the back-translated version of the survey items was reviewed by four management scholars and it was found to be equivalent to the original, indicating that the Arabic version was acceptable for use. Deng et al. (2010) tested and validated the scale of items for customer satisfaction. The items to assess customer loyalty were based on the previous research conducted by Kim et al. (2004), while the items related to service quality, playfulness, intimacy, and trust were taken from Kheiry \& Alirezapou (2012).

The final form of the questionnaire contained 29 items in total. For data scoring, a 5-point Likert scale was used to assess the views of respondents in the sample where the highest score (5) means "Strongly Agree" and the lowest (1) is for "Strongly Disagree". Therefore, the rule of the means relies on the following classification: Less than 2.33 is indicative of Low; the value between 2.34 and 3.66 is indicative of Medium; more than 3.67 is High.

The study population involved users of the Jordanian communication companies in Irbid city including users of Orange, Zain, and Umniah. There is a high number of the users of these 
companies and there is no official frame to select sample members. A sample consisting of 1,000 users were selected to collect data for the study. The sample members were selected randomly in front of each company. We accounted three individuals who entered the prospective companies and distributed the questionnaire to the fourth one to avoid sampling bias as much as possible. We also did so several times a day for the same reason. However, the data was collected in March 2019 over three weeks to collect the data.

Of the total number of questionnaires distributed in the study sample, 627 were valid for further analysis. The response rate was $62.7 \%$ which is comparable to a similar study in the same field. Table 1 shows the demographic characteristics of the respondents in which males $(63.3 \%)$ formed the largest segment of the sample. Also, the highest percentage of the respondents $(52.6 \%)$ were bachelor's degree holders and the greatest proportion of the respondents $(37.2 \%)$ were between 21 and 30 years old. The responses from users of Orange, Zain, and Umniah were $39.7 \%, 31.7 \%$, and $28.5 \%$, respectively.

Tab. 1 - Demographic characteristics. Source: Department of Statistics of Jordan (2017)

\begin{tabular}{|c|c|c|c|}
\hline Variable & Categories & Frequency & $\%$ \\
\hline \multirow[t]{3}{*}{ Gender } & Male & 397 & 63.3 \\
\hline & Female & 230 & 36.7 \\
\hline & Total & 627 & 100.0 \\
\hline \multirow[t]{5}{*}{ Age } & Less than 20 years old & 63 & 10.0 \\
\hline & $21-30$ years old & 233 & 37.2 \\
\hline & $31-40$ years old & 151 & 24.1 \\
\hline & More than 41 years old & 180 & 28.7 \\
\hline & Total & 627 & 100.0 \\
\hline \multirow[t]{6}{*}{ Level of Education } & High school or lower & 57 & 9.1 \\
\hline & Diploma & 136 & 21.7 \\
\hline & B.A. & 330 & 52.6 \\
\hline & Master & 91 & 14.5 \\
\hline & Doctoral & 13 & 2.1 \\
\hline & Total & 627 & 100.0 \\
\hline \multirow[t]{4}{*}{ Mobile Service Provider } & Orange & 249 & 39.7 \\
\hline & Zain & 199 & 31.7 \\
\hline & Umniah & 179 & 28.5 \\
\hline & Total & 627 & 100.0 \\
\hline
\end{tabular}

\section{RESULTS AND DISCUSSION}

Variance-based structural equation modeling with PLS (PLS-SEM) was employed to assess the proposed hypotheses. Even though there has been an extensive ongoing debate as to which circumstances are more or less suitable for PLS-SEM to be used as a method of analysis (Hair 
et al., 2018), it is believed that PLS-SEM is the most suitable instrument for the current study at least for the following reasons. First, the aim of this study is to explore the theoretical extension of the existing marketing theories by inspecting a series of interdependence relationships among loyalty, satisfaction, trust, and other exploratory variables. A complex framework must be used to reach this purpose, thus a superior method is crucial to handle such complexity. Hair et al. (2018) maintained that PLS-SEM is advantageous in such case as it offers a superior statistical power where it is more likely to predict path relationships as significant when they have truly existed in the population (Hair et al., 2018). Second, as a nonparametric method, PLS-SEM imposes lesser constraints on data normal distribution, which is hard to be achieved in behavioral research (Hair et al., 2018). These criteria make PLS-SEM the most appropriate method for this research. Nonetheless, as advocated by Hair et al. (2018), the data analysis was conducted in two stages. The psychometric properties of the measurement model were assessed in the first stage; the structural model was evaluated in the second stage.

\subsection{Measurement model}

All measures employed in this study were constructed as reflective measures. Accordingly, assessment procedures of reflective measurement were implemented, including reliability, convergent,

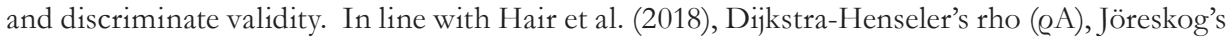
rho ( $\varrho c)$, and Cronbach's alpha $(\alpha)$ were utilized to assess the internal consistency (reliability). The recommended value for these measures is 0.7 and above (Hair et al., 2018). ADANCO software to estimate the structural and measurement models was used. As presented in Table 2, all of the constructs demonstrated a satisfactory internal consistency as the values of Dijkstra-Henseler's rho, Jöreskog's rho, and Cronbach's alpha were well above the threshold value of 0.7 . To examine the convergent validity, item loadings and average variance extracted (AVE) were also inspected. It should be noted that a satisfactory level of convergent validity is established when individual items weigh significantly and sufficiently on their assumed construct and that the AVE of constructs is well above 0.5 (Hair et al., 2018). As indicated in Table 2, all item loadings were significant and ranged between 0.5 and 0.86 with only five items that had a loading of less than 0.7 . Also, the AVEs ranged between 0.52 and 0.62 which were well above the suggested threshold. Accordingly, a reasonable degree of convergent validity of the scales was achieved.

Tab. 2 - Reliability and convergent validity. Source: own research

\begin{tabular}{|l|l|l|l|l|l|l|}
\hline Construct & $\begin{array}{l}\text { Dijkstra-Hensel- } \\
\text { er's rho }\end{array}$ & $\begin{array}{l}\text { Jöreskog's } \\
\text { rho }\end{array}$ & $\begin{array}{l}\text { Cronbach's } \\
\text { alpha }(\alpha)\end{array}$ & AVE & Indicator & Loading \\
\hline $\begin{array}{l}\text { Service } \\
\text { Quality }\end{array}$ & 0.7406 & 0.8157 & 0.7051 & 0.5282 & A3 & 0.652 \\
\hline & & & & & A4 & 0.6376 \\
\hline & & & & & A5 & 0.8175 \\
\hline & & & & & A6 & 0.7828 \\
\hline Playfulness & 0.722 & 0.8415 & 0.7189 & 0.6393 & B1 & 0.7692 \\
\hline & & & & & B2 & 0.7919 \\
\hline
\end{tabular}




\begin{tabular}{|c|c|c|c|c|c|c|}
\hline & & & & & B3 & 0.8361 \\
\hline \multirow[t]{4}{*}{ Intimacy } & 0.848 & 0.8884 & 0.8327 & 0.6667 & C1 & 0.7156 \\
\hline & & & & & $\mathrm{C} 2$ & 0.849 \\
\hline & & & & & C3 & 0.8312 \\
\hline & & & & & C4 & 0.8621 \\
\hline \multirow[t]{4}{*}{ Trust } & 0.8275 & 0.8798 & 0.817 & 0.6479 & D1 & 0.7005 \\
\hline & & & & & D2 & 0.8595 \\
\hline & & & & & D3 & 0.8292 \\
\hline & & & & & D4 & 0.8213 \\
\hline \multirow[t]{4}{*}{ Satisfaction } & 0.7532 & 0.8397 & 0.7446 & 0.5686 & E1 & 0.7248 \\
\hline & & & & & E2 & 0.8244 \\
\hline & & & & & E3 & 0.6696 \\
\hline & & & & & E4 & 0.788 \\
\hline \multirow[t]{4}{*}{ Switching } & 0.7628 & 0.8222 & 0.7128 & 0.5452 & F1 & 0.4978 \\
\hline & & & & & F2 & 0.8467 \\
\hline & & & & & F3 & 0.7276 \\
\hline & & & & & F4 & 0.8287 \\
\hline \multirow[t]{4}{*}{ Loyalty } & 0.7393 & 0.8256 & 0.7211 & 0.5438 & G1 & 0.7283 \\
\hline & & & & & G2 & 0.8087 \\
\hline & & & & & G3 & 0.7658 \\
\hline & & & & & G4 & 0.6359 \\
\hline
\end{tabular}

Next, the square root of the AVEs was employed to examine the discriminant validity. When each construct demonstrates the AVE value, which is greater than its squared inter-construct correlation of other constructs, discriminant validity is maintained. It should be highlighted that the analyses of this study satisfied this condition as presented in Table 3 below. The cross-loading criterion was also used for further confirmation. This criterion suggests that each individual item should weigh greater on their assumed construct as compared to other constructs, which was the case of this study (Table 4). Accordingly, both criteria indicated that all constructs have shown satisfactory discriminant validity.

Tab. 3 - Discriminant validity: the square root of the AVEs; squared correlations; AVE in the diagonal. Source: own research

\begin{tabular}{|l|l|l|l|l|l|l|l|}
\hline Construct & $\begin{array}{l}\text { Playful- } \\
\text { ness }\end{array}$ & Intimacy & Trust & $\begin{array}{l}\text { Satisfac- } \\
\text { tion }\end{array}$ & $\begin{array}{l}\text { Switch- } \\
\text { ing }\end{array}$ & Loyalty & $\begin{array}{l}\text { Service } \\
\text { Quality }\end{array}$ \\
\hline Playfulness & 0.6393 & & & & & & \\
\hline Intimacy & 0.2188 & 0.6667 & & & & & \\
\hline Trust & 0.2021 & 0.6248 & 0.6479 & & & & \\
\hline $\begin{array}{l}\text { Satisfac- } \\
\text { tion }\end{array}$ & 0.2758 & 0.4791 & 0.4674 & 0.5686 & & & \\
\hline
\end{tabular}




\begin{tabular}{|l|l|l|l|l|l|l|l|}
\hline Switching & 0.3255 & 0.5406 & 0.5 & 0.4568 & 0.5452 & & \\
\hline Loyalty & 0.3241 & 0.4017 & 0.448 & 0.3142 & 0.5312 & 0.5438 & \\
\hline $\begin{array}{l}\text { Service } \\
\text { Quality }\end{array}$ & 0.4789 & 0.2238 & 0.3357 & 0.2988 & 0.3501 & 0.4029 & 0.5282 \\
\hline
\end{tabular}

Tab. 4 - Discriminant validity: cross loading. Source: own research

\begin{tabular}{|c|c|c|c|c|c|c|c|}
\hline Indicator & $\begin{array}{l}\text { Service } \\
\text { Quality }\end{array}$ & $\begin{array}{l}\text { Playful- } \\
\text { ness }\end{array}$ & Intimacy & Trust & $\begin{array}{l}\text { Satisfac- } \\
\text { tion }\end{array}$ & $\begin{array}{l}\text { Switch- } \\
\text { ing }\end{array}$ & Loyalty \\
\hline A3 & 0.652 & 0.5468 & 0.2254 & 0.3001 & 0.2818 & 0.3617 & 0.4347 \\
\hline A4 & 0.6376 & 0.458 & 0.2556 & 0.3256 & 0.3093 & 0.295 & 0.3699 \\
\hline A5 & 0.8175 & 0.5368 & 0.4291 & 0.5125 & 0.4811 & 0.5164 & 0.5303 \\
\hline A6 & 0.7828 & 0.5024 & 0.4074 & 0.4896 & 0.464 & 0.4986 & 0.4955 \\
\hline B1 & 0.6331 & 0.7692 & 0.4179 & 0.4863 & 0.4516 & 0.5074 & 0.5306 \\
\hline B2 & 0.4987 & 0.7919 & 0.2637 & 0.2201 & 0.3606 & 0.381 & 0.3449 \\
\hline B3 & 0.5149 & 0.8361 & 0.4192 & 0.3428 & 0.4355 & 0.4646 & 0.4676 \\
\hline C1 & 0.2946 & 0.4274 & 0.7156 & 0.4988 & 0.4822 & 0.5244 & 0.4973 \\
\hline $\mathrm{C} 2$ & 0.3906 & 0.3982 & 0.849 & 0.6395 & 0.6117 & 0.5935 & 0.4957 \\
\hline C3 & 0.3739 & 0.2554 & 0.8312 & 0.7114 & 0.5665 & 0.5834 & 0.4982 \\
\hline $\mathrm{C} 4$ & 0.4686 & 0.4717 & 0.8621 & 0.7025 & 0.5932 & 0.6912 & 0.583 \\
\hline D1 & 0.4367 & 0.3187 & 0.47 & 0.7005 & 0.5036 & 0.5 & 0.4738 \\
\hline $\mathrm{D} 2$ & 0.5205 & 0.4218 & 0.655 & 0.8595 & 0.6081 & 0.6158 & 0.5604 \\
\hline D3 & 0.3828 & 0.3017 & 0.6821 & 0.8292 & 0.4993 & 0.5322 & 0.5027 \\
\hline D4 & 0.5147 & 0.3935 & 0.7144 & 0.8213 & 0.581 & 0.6162 & 0.6056 \\
\hline E1 & 0.4622 & 0.4183 & 0.4148 & 0.4698 & 0.7248 & 0.4543 & 0.4103 \\
\hline $\mathrm{E} 2$ & 0.4324 & 0.4072 & 0.5899 & 0.5817 & 0.8244 & 0.5342 & 0.4962 \\
\hline E3 & 0.3255 & 0.3781 & 0.4886 & 0.4508 & 0.6696 & 0.5069 & 0.3668 \\
\hline E4 & 0.4202 & 0.3819 & 0.589 & 0.5506 & 0.788 & 0.5462 & 0.4082 \\
\hline F1 & 0.3573 & 0.3583 & 0.4943 & 0.4785 & 0.5992 & 0.4978 & 0.3134 \\
\hline $\mathrm{F} 2$ & 0.4986 & 0.4985 & 0.6575 & 0.6278 & 0.533 & 0.8467 & 0.6053 \\
\hline F3 & 0.3696 & 0.3891 & 0.4883 & 0.472 & 0.4195 & 0.7276 & 0.5329 \\
\hline $\mathrm{F} 4$ & 0.5126 & 0.4434 & 0.552 & 0.5316 & 0.5286 & 0.8287 & 0.6372 \\
\hline G1 & 0.4598 & 0.4464 & 0.5344 & 0.4966 & 0.4631 & 0.5369 & 0.7283 \\
\hline G2 & 0.5034 & 0.4582 & 0.5448 & 0.5725 & 0.4851 & 0.6916 & 0.8087 \\
\hline G3 & 0.4601 & 0.3991 & 0.4256 & 0.4751 & 0.3545 & 0.4432 & 0.7658 \\
\hline G4 & 0.4505 & 0.3651 & 0.3262 & 0.4078 & 0.3199 & 0.4268 & 0.6359 \\
\hline
\end{tabular}

Finally, since this study is cross-sectional in nature and based on a self-report survey, the variance of the underlining variables would be susceptible to common method bias (CMB) (Podsakoff et al., 2012). Hence, the correlation-based marker variable technique, one of the most stringent cri- 
teria to assess CMB, was utilized to examine this potential validity issue (Podsakoff et al., 2012). The bivariate correlations of the substantive variables were adjusted to the smallest correlation coefficient, and it was revealed that none of the significant correlations turned non-significant in adjusting for CMB. Moreover, the full collinearity approach was utilized, which is very effective in detecting CMV in PLS-SEM, as suggested by Kock (2017). The analysis revealed that none of the variables had a variance inflation factor above the threshold of 3.3.

\subsection{Structural model (hypotheses testing)}

The hypotheses of this study and the predictive validity of the model were assessed using the PLS algorithm and bootstrapping procedures. Based on the results presented in Table 5 and Figure 1, it was revealed that $57.9 \%$ of the variance in consumer loyalty was explained by trust and switching barriers. Similarly, $68 \%$ of the variance in consumer trust was explained by satisfaction, intimacy, and service quality. Moreover, both service quality and playfulness accounted for approximately $34.2 \%$ of the variance in satisfaction. These figures suggested that the model explained substantial variance in the endogenous variables, thus substantiating the model's predictive validity.

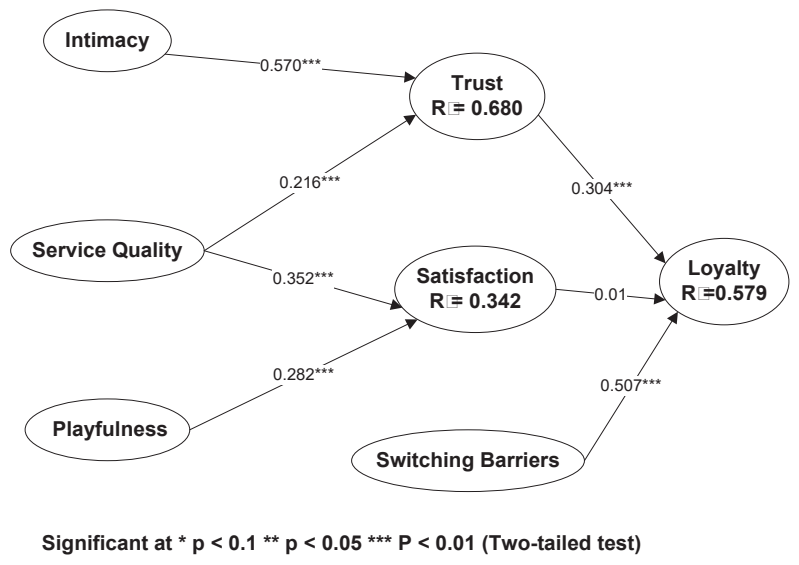

Fig. 1 - The estimation of the structural model. Source: own research

Based on the analysis, it was revealed that the effect of service quality on trust (path coefficient $=$ $0.216, \mathrm{p}<0.001$ ) and satisfaction (path coefficient $=0.352, \mathrm{p}<0.001$ ) were significantly positive, confirming the predictions of hypotheses $\mathrm{H} 1$ and $\mathrm{H} 2$ respectively. The findings also indicated that the effect of playfulness on satisfaction was significantly positive (path coefficient $=0.282$, $\mathrm{p}<0.001$ ), supporting hypothesis H3. Similarly, the effect of intimacy on trust was significantly positive (path coefficient $=0.570, \mathrm{p}<0.001$ ), verifying hypothesis H4. Nonetheless, contrary to the expectations, the influence of satisfaction on loyalty was not statistically significant (path coefficient $=0.01, \mathrm{p}>0.05)$. Therefore, hypothesis $\mathrm{H} 5$ was rejected. It was further discovered that trust and switching barriers were significant predictors of loyalty with path coefficient $=0$. $305 ; \mathrm{p}<0.001$ and path coefficient $=0.507 ; \mathrm{p}<0.001$, respectively. Hence, hypotheses H6 and H7 were empirically supported. 
Tab. 5 - The estimation of the structural model. Source: own research

\begin{tabular}{|l|l|l|l|l|l|}
\hline \multirow{2}{*}{ Effect } & \multirow{2}{*}{$\begin{array}{l}\text { Original } \\
\text { coefficient }\end{array}$} & \multicolumn{4}{l}{ Standard bootstrap results } \\
\cline { 3 - 6 } & & $\begin{array}{l}\text { Standard } \\
\text { error }\end{array}$ & t-value & $\begin{array}{l}\text { p-value } \\
(2 \text {-sided })\end{array}$ & $\begin{array}{l}\text { p-value } \\
(1 \text {-sided })\end{array}$ \\
\hline Playfulness $\rightarrow$ Satisfaction & 0.282 & 0.046 & 6.155 & 0.000 & 0.000 \\
\hline Intimacy $\rightarrow$ Trust & 0.570 & 0.038 & 15.137 & 0.000 & 0.000 \\
\hline Trust $\rightarrow$ Loyalty & 0.304 & 0.052 & 5.844 & 0.000 & 0.000 \\
\hline Satisfaction $\rightarrow$ Loyalty & 0.010 & 0.040 & 0.251 & 0.802 & 0.401 \\
\hline Switching $\rightarrow$ Loyalty & 0.507 & 0.050 & 10.201 & 0.000 & 0.000 \\
\hline Service Quality $\rightarrow$ Trust & 0.216 & 0.034 & 6.463 & 0.000 & 0.000 \\
\hline Service Quality $\rightarrow$ Satisfaction & 0.352 & 0.046 & 7.715 & 0.000 & 0.000 \\
\hline
\end{tabular}

\subsection{Discussion}

The results reported in this study also correlate with those of several previous studies (Turel \& Serenko, 2006) in which it has been suggested that service quality is the key factor in customer satisfaction. This means that customers will be more satisfied when the service provider delivers a higher quality of goods and services. Similar to the study conducted by Turel \& Serenko (2006), it can be suggested that service quality also determines how to induce customers satisfaction with their mobile service provider.

The outcomes also suggest that there was a statistically significant effect of playfulness on customer satisfaction; the quality of a good relationship induces customers to stay with the current service provider. Service quality was found to be an important factor for both satisfaction and trust in this study with statistical significance. The results of the study also confirmed a statistically significant impact of playfulness on customer satisfaction. Therefore, playfulness is a significant contributor of customer satisfaction, a finding that is consistent with reports by Kheiry \& Alirezapou (2012) in their studies.

With regard to intimacy, the results indicated a statistically significant impact of intimacy on customer trust. This relationship implies that a higher level of intimacy signifies the presence of a high level of trust among customers, which is very significant for service providers. In this respect, Boshoff \& du Plessis (2009) asserted that intimacy in the context of mobile telecommunication services could be achieved by following through with agreements and keeping promises in terms of service delivery, showing confidence in the service provider, and assuring that the customers will receive high-quality services. These steps will result in increasing customer trust toward the mobile service provider.

Furthermore, the findings showed that there was no statistically significant effect of customer satisfaction on customer loyalty. Instead, this study discovered a negative impact of satisfaction on customer loyalty. It should be highlighted that satisfaction does not always lead to customer loyalty, as it is natural to assume that satisfied customers will have a higher level of loyalty. As the current study focuses on measuring the overall satisfaction level among mobile service customers and its relationship with customer loyalty, this result is consistent with that of previous studies 
(Turel \& Serenko, 2006). This means that customers in the Jordanian telecommunication sector will not remain loyal to their mobile service providers.

In terms of the association between trust and loyalty, the findings illustrate that there was a statistically significant effect of trust on customer loyalty. The study indicated a positive and significant impact of perceived trust on customer loyalty, a finding that has also been confirmed in the existing literature (Deng et al., 2010; Kheiry \& Alirezapou, 2012). These studies concluded that there is a need to emphasize the crucial role played by trust and switching barriers in determining the level of customer loyalty level.

The findings also revealed that there was a statistically significant effect of switching barriers on the loyalty of mobile telecommunication service users.

\subsection{Limitations}

Despite certain limitations, the research value of the study is not undermined. First, the reliance on self-report measures for all key variables in the current study increases the possibility of common method bias. In order to overcome this drawback, previously validated scales were used in addition to conducting the correlation-based marker variable technique as one of the most stringent criteria to assess CMB. Second, due to the wide geographical distribution of mobile telecommunication branches throughout the kingdom, the distribution of questionnaires proved to be a highly time-consuming process; this may make replication of results under similar circumstances difficult. Third, although PLS-SEM offers greater statistical power, it has received many scholarly criticisms, such as those pertaining to the lack of quality indices and the inability to capture measurement error (Hair et al., 2018). Thus future research should employ other SEM approaches to offset such limitations (e.g., Amos). Finally, since this study is the first of its kind in Jordan, there is a limited benefit in comparing its findings with those of other studies whose context is vastly different. Therefore, it would be useful to investigate this topic in other sectors so that the generalization of the results across different industries can be made.

\section{CONCLUSION}

In our study, the business strategies of mobile telecommunication service providers were examined in terms of their ability to increase the loyalty of service users in Jordan. It has been revealed that the factors of service quality, playfulness, and intimacy have a positive effect on the trust and satisfaction of mobile telecommunication service users. Switching barriers also has a significant effect on customer loyalty. Not only do the customers look for superior service quality in mobile telecommunication services, but they also seek to develop intimate and trustworthy relationships with the service providers. Hence, a playfulness program is essential to distinguish a service provider from competitors. Long-lasting loyal relationships are more likely to be developed when the company is able to enhance and maintain customer satisfaction.

\subsection{Managerial implications}

Several managerial implications can be provided based on the research outcomes. First, mobile operators must maximize customer satisfaction by focusing on service quality. With regard to 
switching barriers, mobile operators should offer client-oriented services to increase customer satisfaction and customer loyalty. Simultaneously, attempts to raise the switching barriers should include building a long-term communication with clients by investing in client relationship management. Second, the intimacy of the service provider-customer relationship should be maintained in the effort to establish the quality of services by educating customer service reps, as well as call center and front line employees. Finally, service providers should ensure trustworthy relationships by providing and updating a number of playful elements.

While mobile operators have focused on improving the quality of call reception and distribution over the last few years via huge investments in equipment, call coverage, and clarity, overall service quality is not the only factor which increases high customer satisfaction. Mobile operators should dedicate their efforts toward developing value-added services for increased convenience and enjoyment for customers. In terms of the customer support field, providers should minimize nuisances for clients by processing customer complaints more quickly via an array of diverse channels and systems. With regard to the factors which essentially affect switching barriers, such as switching price, loss price, move-in price, and interpersonal connections, reward programs should be constantly developed, including price discounts and mileage programs. Moreover, interpersonal connections between clients and carriers are a feature that encourages clients to remain with a provider even though competitors try to pull clients to their side through offers of lower prices and other conveniences. Lastly, switching barriers was revealed as having a limited regulation effect on customer satisfaction and loyalty. Today, consumers are easily able to compare the offers of competitive enterprises and choose the one that offers more adapted products. The individualization of services is a key competitive advantage. Finally, enterprises should make sure they are in constant communication with customers to improve the quality and accessibility of their services.

\section{References}

1. Apostolos, G., \& Evangelos, T. (2017). An integrated model of the effects of service evaluation, corporate image, and switching barriers on customer loyalty. Journal of Transnational Management, 22, 4-2. https://doi.org/10.1080/15475778.2017.1274612

2. Avramakis, E. (2011). Relationship management in Swiss financial services: an investigation into relationship and bonding values of highly-involved and confident customers [Doctoral dissertation, Southern Cross University, Lismore, NSW].

3. Boshoff, C., \& duPlessis, F. (2009). Services Marketing: A Contemporary Approach. Cape Town: Juta and Company Ltd.

4. Budianto, A. (2019). Customer loyalty: quality of service. Journal of management review, 3 (1), 299-305. http://dx.doi.org/10.25157/jmr.v3i1.1808

5. Chang, Y. H., \& Chen, F. Y. (2007). Relational benefits, switching barriers and loyalty: study of airline customers in Taiwan. Journal of Air Transport Management, 13, 104-109. https://doi. org/10.1016/j.jairtraman.2006.10.001

6. Cheng, C. C., Chiu, S. I., Hu, H. Y., \& Chang, Y. Y. (2011). A study on Exploring the Relationship between Customer and Loyalty in the Fast Food Industry: With Relationship Inertia as a Mediator. African Journal of Business Management, 5 (13), 5118-5126. https://doi. org/10.5897/AJBM10.870 
7. Colwell, S., \& Hogarth-Scott, S. (2004). The effect of cognitive trust on hostage relationships. Journal of Services Marketing, 18 (5), 384-394. https://doi.org/10.1108/08876040410548302

8. Dabholkar, P. A., \& Sheng, X. (2012). Consumer Participation in Using Online Recommendation Agents: Effects on Satisfaction, Trust, and Purchase Intentions. The Service Industries Journal, 32 (9), 1433-1449. https://doi.org/10.1080/02642069.2011.624596

9. Danish, R., Humayon, A., Iqbal, H., Raza, S., \& Shahid, J. (2018). The Impact of Service Quality and Service Value on Customer Satisfaction through Customer Bonding: Evidence from Telecommunication Sector. European Online Journal of Natural and Social Sciences, 7 (1), $40-47$.

10. Deng, Z., Lu, Y., Wei, K. K., \& Zhang, J. (2010). Understanding customer satisfaction and loyalty: An empirical study of mobile instant messages in China. International journal of information management, 30 (4), 289-300. https://doi.org/10.1016/j.ijinfomgt.2009.10.001

11. Department of Statistics of Jordan. (2017). Department of Statistics Website. http://www.dos. gov.jo/

12. Didki, W., Timoticin, K., \& Rianthi, S. (2018). The Impact of After-sales Service Quality on Housings. Journal Teknik Industry, 20 (1), 65-72. https://doi.org/10.9744/jti.20.1.\%25p.

13. Hair, J. F., Risher, J. J., Sarstedt, M., \& Ringle, C. M. (2018). Article information : When to use and how to report the results of PLS-SEM. European Business Review, 30 (11), 3192-3210. https://doi.org/10.1108/EBR-11-2018-0203

14. Hong, I. B., \& Cho, H. (2011). The Impact of Consumer Trust on Attitudinal Loyalty and Purchase Intention in B2C E-marketplace: Intermediary Trust vs. Seller Trust. International Journal of Information Management, 31 (2011), 469-479. https://doi.org/10.1016/j. ijinfomgt.2011.02.001

15. Howshigan, S., \& Ragel, V. (2018). The Effectiveness of Switching Barrier on Customer Loyalty Mediated with Customer Satisfaction: Telecommunication Industry, Batticaloa. South Asian Journal of Social Studies and Economics, 2, 1-9. https://doi.org/10.9734/sajsse/2018/ v2i225833

16. Huddleston, P., Whipple, J., Mattick, R. N., \& Lee, S. J. (2009). Customer Satisfaction in Food Retailing: Comparing specialty and conventional grocery stores. International Journal of Retail and Distribution Management, 37 (1), 63-80. https://doi.org/10.1108/09590550910927162

17. Jahanzeb, S., Tasneem, F., \& Khan, B. (2011). An empirical analysis of customer loyalty in Pakistan's telecommunication industry. Database Marketing and Customer Strategy Management, 18 (1), 5-15.

18. Kalia, P., Kaur, N., \& Singh, T. (2017). Consumer Satisfaction in E-shopping: An Overview. Indian Journal of Economics and Development, 13, 569-576.

19. Kheiry, B., \& Alirezapou, M. (2012). The effect of satisfaction, trust and switching barriers service provider on customer loyalty (Mobile phone users of Iran Cell Company in Iran). Australian Journal of Basic and Applied Sciences, 6 (12), 52-60.

20. Kim, M. K., Park, M. C., \& Jeong, D. H. (2004). The effects of customer satisfaction and switching barrier on customer loyalty in Korean mobile telecommunication services. Telecommunications policy, 28 (2), 145-159 https://doi.org/10.1016/j.telpol.2003.12.003 
21. Kock, N. (2015). Common method bias in PLS-SEM : A full collinearity assessment approach. International Journal of E-Collaboration, 11 (4), 1-10. https://10.4018/ijec.2015100101

22. Lee, H. S. (2010). Factors Influencing Customer Loyalty of Mobile Service: Empirical Evidence from Koreans. Journal of International Banking and Commerce, 15 (2), 1-14.

23. Lee, J.J., Kyle, G. and Scott, D. (2012). The mediating effect of Place Attachment between Festival Satisfaction and Loyalty to the Festival Hosing Destination. Journal of Travel Research, 51 (6), 754-767. https://doi.org/10.1177/0047287512437859

24. Liang, T. P., Li, Y. W., \& Turban, E. (2009). Personalized services as empathic responses: The role of intimacy. PACIS 2009 Proceedings, 73.

25. Lin, H. H., \& Wang, Y. S. (2006). An Examination of the Determinants of Customer Loyalty in Mobile Commerce Contexts. Information and Management, 43, 271-282. https://doi. org/10.1016/j.im.2005.08.001

26. Liu, C. T., Guo, Y. M., \& Lee, C. H. (2011). The effects of relationship quality and switching barriers on customer loyalty. International Journal of Information Management, 31 (1), 71-79. https:// doi.org/10.1016/j.ijinfomgt.2010.05.008

27. Nesset, E., \& Helgesen, Ø. (2014). Effects of switching costs on customer attitude loyalty to an airport in a multi-airport region. Transportation Research Part A: Policy and Practice, 67, 240 253. https://doi.org/10.1016/j.tra.2014.07.003

28. Nien-Te, K., Kuo-Chien, C., Yi-Sung, C., \& Jui-Chou, L. (2016). Effects of Tour Guide Interpretation and Tourist Satisfaction on Destination Loyalty in Taiwan's Kinmen Battlefield Tourism: Perceived Playfulness and Perceived Flow as Moderators. Journal of Travel and Tourism Marketing, 33, 103-122. https://doi.org/10.1080/10548408.2015.1008670

29. Orel, F. D., \& Kara, A. (2014). Supermarket self-checkout service quality, customer satisfaction, and loyalty: Empirical evidence from an emerging market. Journal of Retailing and Consumer Services, 21, 118-129. https://doi.org/10.1016/j.jretconser.2013.07.002

30. Podsakoff, P. M., MacKenzie, S. B., \& Podsakoff, N. P. (2012). Sources of Method Bias in Social Science Research and Recommendations on How to Control It. Annual Review of Psychology, 63 (1), 539-569. http://doi.org/10.1146/annurev-psych -120710-100452

31. Pontiskoski, E., \& Asakawa, K. (2009). Overcoming barriers to open innovation at Apple, Nintendo and Nokia. World Academy of Science, Engineering and Technology, 53, 372-377.

32. Pura, M. (2005). Linking perceived value and loyalty in location-based mobile services. Managing Service Quality: An International Journal, 15 (6), 509-538.

33. Ratanavaraha, V., Jomnonkwao, S., Khampirat, B., Watthanaklang, D., \& Iamtrakul, P. (2016). The complex relationship between school policy, service quality, satisfaction, and loyalty for educational to bus services: A multi-level modeling approach. Transport Policy, 45, 116-126. https://doi.org/10.1016/j.tranpol.2015.09.012

34. Sandada, M. (2013). Strategic Planning and its Relationship with the Performance of Small and Medium sized enterprises in Gauteng [Unpublished doctoral dissertation]. Vaal University of Technology, South Africa].

35. Sirdeshmukh, D., Singh, J., \& Sabol, B. (2002). Consumer trust, value and loyalty in relational exchanges. Journal of Marketing, 66, 15-37. https://doi.org/10.1509/jmkg.66.1.15.18449 
36. Tsai, C. T. S., \& Wang, Y. C. (2017). Experiential value in branding food tourism. Journal of Destination Marketing and Management, 6 (1), 56-65. https://doi.org/10.1016/j.jdmm.2016.02.003

37. Turel, O., \& Serenko, A. (2006). Satisfaction with mobile services in Canada: An empirical investigation. Telecommunications Policy, 30, 314-331. https://doi.org/10.1016/j.telpol.2005.10.003

38. Valenzuela, F. (2012). The Effect of Switching Barriers Types on Customer Loyalty 2018 European Online. International Review of Business Research Papers, 8, 1-19.

39. Yoo, D. K., \& Park, J. A. (2007). Perceived service quality: Analyzing relationships among employees, customers, and financial performance. International Journal of Quality and Reliability Management, 24 (9), 908-926. https://10.1108/02656710710826180

40. Zeithaml, V. A., Wilson, A., \& Bitner, M. J. (2008). Services marketing (4th edition). New Delhi: The McGraw-Hill Companies.

41. Zhang, J., Li, D., \& Fan, X. (2018). A Customer-Centric Trust Evaluation Model for Personalized Service Selection. Hindawi Scientific Programming, 2018, 1-15. https://doi. org $/ 10.1155 / 2018 / 4819195$

\section{Contact information}

Muath Alkhurshan, Ph.D. Candidate

Cyprus International University

Faculty of Economics and Administrative Sciences

Department of Business Administration

Turkey

E-mail:alkhurshan@yahoo.com

Assist. Prof. Husam Rjoub, Dr.

Cyprus International University

Faculty of Economics and Administrative Sciences

Department of Accounting and Finance

Turkey

E-mail:brjoub@ciu.edu.tr

ORCID:0000-0001-6536-8971 